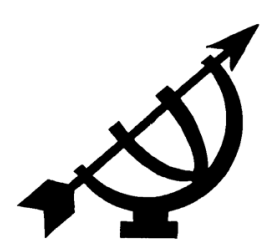

\title{
Metaphor: the intertwinement of thought and language
}

\author{
D.F.M. Strauss \\ Department of Philosophy \\ University of the Free State \\ BLOEMFONTEIN \\ E-mail: dfms@cknet.co.za
}

\begin{abstract}
Metaphor: the intertwinement of thought and language

The analysis of this article aims at reflecting on the nature of metaphoricity within the context of thought and language inspired by the contributions of Elaine Botha in this regard commencing about three decades ago. This paved the way for those who were working within the tradition of reformational philosophy to take a new look at the nature of metaphor.
\end{abstract}

Since thinking and talking are concrete activities in principle functioning in all aspects of reality, they cannot as such provide criteria to decide on the order relationship between the logicalanalytical and lingual aspects of reality. It turns out that, without a proper view of the differences between concept and word, an account of the nature of metaphor remains inconsistent. Universal traits, logical objectification, and the conceptual unknowability of what is individual, surfaces in the article. The foundational role of spatial relationships appears to be linked to imaging and imagining, informing the proposal to differentiate between modally and entitary directed knowing.

The linguistic turn in particular inspired a renewed interest in language and the central place of metaphorical language use. After considering the connections between analogy and metaphor a new approach to the distinction between modal analogies and metaphors is proposed - one that is geared towards the interconnections between the different dimensions of our experiential world. The last part is dedicated to Lakoff and Johnson (1999) who have developed a peculiar view of the "embodied mind", "conceptual metaphor", and "cross-domain mappings", while the article concludes with an argument about 
the limits of substitution and take into account expanded conditions.

\section{Opsomming}

\section{Metafoor: die verstrengeling van gedagtes en taal}

Die ontleding van hierdie artikel is gerig op die aard van metafore binne die konteks van taal en denke - geïnspireer deur die bydraes van Elaine Botha oor hierdie problematiek wat sowat dertig jaar gelede begin het. Dit het die weg gebaan vir diegene wat binne die reformatories-wysgerige tradisie werk om met nuwe oë na metafore te kyk.

Aangesien denke en taalgebruik konkrete aktiwiteite is wat in beginsel in alle werklikheidsaspekte funksioneer, kan dit as sodanig nie maatstawwe bied met behulp waarvan die orderelasie tussen die logies-analitiese en die linguale aspekte van die werklikheid bepaal kan word nie. Dit blyk dat rekenskap van die aard van 'n metafoor nie op 'n konsistente wyse gegee kan word, sonder 'n verantwoorde siening van die verskille tussen 'n begrip en 'n woord nie. Universele trekke, logiese objektivering, begripskennis, en die begripsmatige onkenbaarheid van wat individueel is, verskyn ook in die artikel. Die funderende rol van ruimteverhoudings skyn verbind te wees aan beeldvorming en verbeelding, wat die voorstel ondersteun om tussen modaal- en entiteitsgerigte kennis te differensieer.

Dit was egter die sogenaamde linguistieke ommeswaai wat hernude belangstelling in taal en in die sentrale plek van metaforiese taalgebruik geïnspireer het. Deur te let op die verband tussen analogie en metafoor word 'n nuwe benadering tot die onderskeid tussen modale analogieë en metafore voorgestel een wat gerig is op die verbindingslyne tussen die verskillende dimensies van die werklikheid. Die laaste gedeelte word gewy aan Lakoff en Johnson (1999) wat 'n besondere siening van die "embodied mind", "conceptual metaphor", en "cross-domain mappings" ontwikkel het, terwyl afgesluit word met 'n argument insake die grense van substitusie en die verdiskontering van meer uitgebreide kondisies.

\section{Introduction}

Within the circles of reformational philosophy, Elaine Botha certainly deserves credit for being the first one who thoroughly entered the field of philosophical reflection on the nature of metaphor - culminat- 
ing in her recent book published by Peter Lang. ${ }^{1} \mathrm{~A}$ fundamental aspect of this theme will be investigated in this article - metaphoricity in the light of the interconnections between thought and language as well as the order relation between them. In line with the theoretical approach of Elaine Botha, this article proceeds from the biblically informed ideal of achieving a non-reductionist understanding of reality, in the context of discerning both the uniqueness of thought and language and attempting to avoid reducing either of them to the other. The attempt to reduce what is truly unique to something else invariably leads to the deification of something or some aspect within creation, normally accompanied by imperialistic "all"-claims such as, "everything is number", "everything is matter", "everything is rational", or "everything is interpretation". The distortions thus created inevitably result in insoluble antinomies. A Christian approach to scholarship, directed by the central biblical motive of creation, fall and redemption and guided by the theoretical idea that God subjected all of creation to his law-Word, which delimits and determines the cohering diversity we experience within reality, in principle safeguards those in the grip of this ultimate commitment and theoretical orientation from absolutising anything within creation, although in fact we often do not escape from misunderstanding the diversity within creation. The method applied will largely be modal analysis - accounting for the uniqueness and mutual coherence between aspects and their relation to entities. It will turn out that a new understanding of metaphoricity flows from the analogical mapping between aspects, between entities, between aspects and entities and between entities and aspects. One may call the approach explored in this article transcendental-empirical. Its aim is to observe our experience of thought and language by asking what underlying (transcendental) conditions make this experience possible.

Contemplating the relationship between thought and language is perhaps as old as philosophy itself. Various positions were assumed ever since Lao Tse said that "a thought once uttered is a lie". Early Greek philosophy soon explored an alternative option, paticularly in the claim of Parmenides that "thought and being are the same"

1 This excellent work by Botha (2007) explores a theme indirectly related to our current discussion on metaphor in the context of thought and language although what is later introduced in our discussion, regarding the conditioning role of interdimensional connections for different kinds of metaphor, may prompt Botha to consider the expansion of the scope of metaphors and the strict distinction between modal analogies and metaphors. 
(Diels \& Krantz, B.3). ${ }^{2}$ In his characterisation of being the employment of spatial properties are prominent, namely continuity and the whole-parts relation. The B Fragments 2 and 3 of Parmenides hold that being "... was not and will never be because it is connected in the present as an indivisible whole, unified, coherent" (DielsKrantz, B.8.3-6). ${ }^{3}$ The subsequent development of philosophy, particularly during the Middle Ages, further explored this idea.

In retrospect, this turned out to be the starting point of the subsequent metaphysics of being with its inherently rationalistic undertones - elevating human thought to be capable of encompassing anything, even reaching to the rank of what is divine, with God envisaged as the ipsum esse, the Highest Being. Since creatures were supposed to participate in this highest being, an account was needed to explain the relationship between God and creatures. Such an account was found in the theory of the analogy of being (analogia entis). All creatures are in God according to their highest being. Thomas Aquinas (1964) holds that we can know God through his creatures, because in an eminent way God bears all the perfections of things within Himself. Within God they are one, but we know God by means of these perfections as they flow from Him into (the multiplicity of) creatures (procedentibus in creaturas ab ipso Thomas Aquinas, 1964:1.13.3).

This legacy opened the way to an appreciation of the problem of similarities and differences, which is related to the notion of analogy. When Aristotle discusses metaphor, he distinguishes four categories, mentioning naming on grounds of analogy fourth:

Metaphor consists in giving the thing a name that belongs to something else; the transference being either from genus to species, or from species to genus, or from species to species, or on grounds of analogy. (Aristotle, 2001:1476 - Poetics, 1457:b.8-10.)

2 Parmenides only adds language, as an utterance, after thought and being has been identified: "Thinking and the thought that it is are the same; for you will not find thought apart from what is, in relation to which it is uttered." (Diels \& Krantz, B.8.34-36.) The legacy of Parmenides is mainly observed in that the metaphysics of being is actually a space metaphysics, supplemented by the idea of an analogy of being. See the text below.

3 In following certain insights of Anaxagoras we find that Aristotle realised that "everything continuous is divisible into divisible parts which are infinitely divisible" (Aristotle, 2001:317 - Physica, 231:b.15 ff.). 
The underlying question is how such a metaphorical name-giving is possible? It appears that apart from relations between named things, no metaphorical use of words or language is possible. However, such an understanding of these relations is embedded in human awareness of space, because spatial relationships enable the discerning and distinguishing of spatial figures. Just think of lines, squares, rectangles, triangles and spheres. Although we always relate spatial figures to concrete configurations of things and processes in our non-scientific experience, we simultaneously have an implicit knowledge of the underlying spatial conditions making possible the concrete shapes and forms of our everyday life.

Noticing similar patterns opens up the possibility for figurative speech or language use, which is, therefore, also dependent upon the foundational importance of spatial relationships. ${ }^{4}$ Eibl-Eibesfeldt (2004) speaks of the spatial intelligence of human beings which, for him, highlights the ability to "grasp" spatial relationships in a centered way. He holds that our thinking is spatial, combined with the ability to translate invisible relationships into conceptual representations (Eibl-Eibesfelct, 2004:747).

The reason why spatiality is important for thought is that as soon as the nature of a concept is contemplated we think of definitions which delimit or demarcate what is grasped from what is not grasped. In fact Plato already claimed in his dialogue, Parmenides, that thinking being entails that at once non-being is also thought of. This insight actually highlights the reciprocity of identification and distinction which constitute the two most fundamental "legs" of logical thinking. Identifying something relates to an awareness of the distinctness of whatever is identified and the latter implicitly refers to the discrete meaning of number - every number is distinct from every other number. Within the domain of logical analysis, distinction represents the ever-present counterpart of identification, because in order to identify, one has to distinguish and vice versa. This mutual relationship crucially depends upon the nature of concepts, for the latter is fitted within the logical subject-object relation. A concept unifies a multiplicity of logically objectified (universal) features. The necessary presence of universal traits that are, via logical objectification, brought together in the unity of a concept entails that concepts are

$4 \quad$ While acknowledging the importance of the whole-parts structure of physical entities for basic level categories, Lakoff and Johnson (1999:28 ff.) do not realise that the whole-parts relation has its original modal seat within the aspect of space (cf. Strauss, 2009:87, 181, 236, 302 ff., 353 ff.). 
blind to what is individual. This provides a strong argument for distinguishing between conceptual knowledge and concept-transcending knowledge. Interestingly, whereas concepts are blind towards what is individual, 5 both the senses and human language appears to transcend this limitation. Already during the Middle Ages it was acknowledged that sensory perception can "tract down" what is individual, while language is known for its ability to "point at" in a truly deictic sense. Does this mean that language is foundational to logical analysis, or is it rather the other way around?

\section{The order relation between the logical and the lingual}

Let us start by mentioning a few succinct remarks found in the fifteenth edition of Encyclopedia Britannica (1975) on metaphor. It is, first of all, described as a "figure of speech" based upon "an implicit comparison of two unlike entities" (Encyclopedia Britannica, 1975: 831). The specification "unlike" precludes entities of the same type, but does not deny that similar (kinds of) entities are still distinct. 6 This article proceeds by saying that a "metaphor makes a qualitative leap from a reasonable, perhaps prosaic, comparison to an identification or fusion of two objects", that is, "to make one new entity partaking of the characteristics of both". While the words "like" or "as" marks the explicit comparison present in a simile, the word "is" designates the subtle identification present in a metaphor. But do we really get a new entity ${ }^{7}$ It is, therefore, not surprising that this article (Encyclopedia Britannica, 1975) records that many "critics regard the making of metaphors as a system of thought antedating or bypassing logic".

Of course the decisive question is: What kind of "identification" takes place in metaphorical language use? If it is understood in a strictly logical sense, the inevitable conclusion would be that something

$5 \quad$ This was already realised by Aristotle (2001:799 - Metaph. 1036a.8-9) and as recently as 1952 De Vleeschauwer still emphasises the fact that "knowledge of what is individual is simply impossible" - something about which philosophy, according to him, has had clarity since its inception (De Vleeschauwer, 1952:213).

6 Suppose we consider the category of "flying entities", then one may encounter a metaphor in which reference is made to the "wing" of the aeroplane. It seems as if we have a higher level similarity and a lower level difference - "flying" encompasses both natural and artificial flying entities.

7 When a metaphor is understood as a form of predication, the problem of "illogical" identification disappears (cf. Köller, 1975). 
illogical is involved. Black (1979:21) discerns something similar in a metaphorical statement:

So perhaps the 'mystery' is simply that, taken as literal, a metaphorical statement appears to be perversely asserting something to be what it is plainly known not to be.

What Black calls "taken as literal" could be rephrased by pointing out that asserting the impossible appears to be prominent when metaphorical language is understood in a strictly logical sense. This suggests that the logical mode of identifying and distinguishing is intimately connected to metaphors even if it cannot be equated with it. How are we to disentangle the thought and lingual elements coconditioning metaphorical language use?

It does not help to argue that thinking and speaking function in all aspects of reality, because this insight does not elucidate the order relation between the logical and the lingual. However, we are getting closer to an understanding of this problem when we consider the fact that the logical sense of children appears to develop more rapidly than their linguistic abilities and competence. Consider the following striking example. A little girl, who first notices a pigeon and learns its name, can abstract "concretely", for instance when she shortly thereafter refers to a shrike as a pigeon. The child actually designates the concept "bird" with the name (verbal sign) "pigeon". This is only possible, because from the concrete sensorially perceived image of a pigeon, the girl has lifted out certain bird-characteristics, e.g. a beak, wings, feathers, while simultaneously relinquishing the specific characteristics that distinguish a pigeon from a shrike.

This kind of abstraction is part of our everyday life, since ordinary people are continually classifying (identifying) all sorts of entities by placing them within certain categories. Otherwise, how would one be able to identify a particular horse as a horse (i.e. belonging to the category of horses), or a particular car as a car? Without general concepts, such as cars and horses (in which the detail of particular cars and horses are relinquished), this would be impossible.

This example shows that within the intellectual development of human beings, logical concept formation precedes matching lingual abilities. Viewed from the perspective of the distinctness of, and co- 
herence between modal aspects, language use is built upon the basis of logical skills. 8

All language, including metaphorical language use, is based upon the ability of lingual identification and lingual distinction, presupposing the original logical-analytical meaning of identification and distinction. An important difference between these two aspects is observed when a concept and a word are compared. Consider the concept of a circle and of a square. Clearly, as Kant already argued, it is illogical to confuse these two - in a logical sense there is no "square circle". 9 Yet, in a lingual context, we may focus on merely one element of the meaning nuance of the word "circle", namely "an enclosed space". Then the word can easily be combined in the wellknown metaphor of a "boxing ring". While the concept of a square and the concept of a circle bring with them every element analytically implied by them, our lingual abilities, embracing all the typical semantic features (such as synonymity, ambiguity, metaphoricity, etc.), may isolate particular meaning-nuances as is the case in the lingual expression "boxing ring". If these two words brought with them everything entailed by their corresponding concepts, it would simply have led to contradiction. This example shows that what has been correctly logically objectified, within the context of languageuse, thereby manifesting the foundational position of concepts, may transcend the restrictions of logicality in metaphorical language-use.

In a different context, Dooyeweerd (1938) advances another argument for positioning the cultural-historical aspect (and the lingual aspect) after the logical-analytical aspect. He refers to instances in which the process of meaning disclosure manifests itself within the cultural-historical and post-cultural-historical aspects, without affecting a deepening of non-theoretical thought to the level of the systematic mastery of a given cognitive domain. Because formative

8 Within the Afrikaans language, a quite interesting example of this foundational relationship is found. The double negation in the Afrikaans language generates a logic peculiar to the language itself. It is found that relatively young children (35 years), who display a clear sense of logical consistency and logical soundness, answer questions phrased in terms of the double negation with "yes", where older children and adults, who have matured lingually to such an extent that they are "at home" with the (apparently "illogical") double negation of Afrikaans, would say "no". In Afrikaans one may ask: "Is jy nie honger nie?" ("Aren't you hungry?") A young child will answer yes whereas more mature language users would say no.

$9 \quad$ See his Prolegomena zu einer jeden künftigen Metaphysik die als Wissenschaft wird auftreten können (Kant, 1969 [1783]:341; § 52b). 
control (mastery) reveals the unclear meaning of the historical aspect, and since scholarly reflection requires this deepened meaning of analysis, it must be clear that the rise of truly scientific thought is dependent upon the disclosure of the logical-analytical mode, and the anticipation of the meaning of the historical modality as an aspect coming after the logical aspect in the order of cosmic time. It is, therefore, also striking that the historicistic mode of thought accepts science as a "cultural factor" - to the exclusion of non-scientific thought (Dooyeweerd, 1938:33; 61, footnote 49 \& 50).

Regarding the order of aspects the cultural-historical aspect is presupposed within the structure of the sign mode.10 If this view is accepted, an argument showing that the logical aspect precedes the historical is sufficient to conclude that it also precedes the sign mode, on the basis of transitivity: if $B<C$ and if $A<B$, then $A<C$.

\section{Logical thinking and imagining}

The close connection between thinking, spatiality and imaging may open up another avenue to understand the relationship between thought and language - one that is focused on logical conceptualisation and imagining. 11

Mäckler (2000:30) mentions the following definition of art by Croce: "Art is intuition, intuition is individuality and individuality does not repeat itself."12 Human knowing indeed appears to be coconditioned by the two fundamental dimensions of reality, namely knowledge of modal aspects and knowledge of entities. The former is known through functional relations and the latter through imaging that takes the shape of imagining in our uniquely human acquaintance with the world. These two legs of knowing - modally directed and entitary directed - imply each other and open the way to account for our knowledge of universality and individuality. Compare Croce's following conceptions of these forms of knowledge:

10 Verburg (1951:31) speaks of the "formative-instrumental substrate within language".

11 Since all our non-theoretical concepts are actually conceptual representations, it is clear that spatial forms are crucial in non-theoretical thinking, showing that spatiality is a foundational to thinking and imaging, i.e. to conceptual representations. nicht." 
He states that knowledge has two forms: it is either intuitive knowledge or logical knowledge; knowledge obtained through the imagination or knowledge obtained through the intellect; knowledge of the individual or knowledge of the universal; of individual things or of the relations between them: it is, in fact, productive either of images or of concepts. (Croce, 1953:1; italics - DFMS.)

Surely imaginativity, as the manifestation of a specific directedness of human knowing towards the dimension of (individual) entities, extends across this entire dimension and cannot be restricted to aesthetic imaginativity alone - as suggested by Seerveld (1968:45; 1979:284; 1980:132; 2001:175). In addition, the flexibility of human understanding allows for a cross-utilisation between the two dimensions of human experience, since the modal aspects serve as points of entry to an understanding of entities. The nature of the modal aspects, on the other hand, can only be explained with the aid of metaphors which are the result of imaginatively relating different kinds of entities through predication. Yet our knowledge of concrete entities embraces both their universality (belonging to some or another type), and their individuality. Therefore, the difference between what is universal and individual does not coincide with the difference between the logical and the lingual.

Although neo-Darwinists claim that animals and humans are similar, because animals not only use tools, but make them as well, archeologists emphasise the human formative imagination which is capable of inventing something different from what is presented to the senses (cf. Narr, 1976). This view is complementary to Kant, who defines the Einbildungskraft (imagination) as the capacity to have a representation of an object without its presence to the senses (Kant, 1969 [1787]-B:151). This enables human beings to have a historical awareness: memory (historical past) and expectations or planning (historical future) - while animals are said to live in the now.

In reaction to the conceptual rationalism of the eighteenth century and the historicism of the nineteenth century, the linguistic turn started to explore an alternative option. Participating in this linguistic turn, Heidegger and Gadamer realised that language itself may be emphasised to escape from the relativism of historicism. Van Niekerk (1993:39) acknowledges this step when he points out that, according to Gadamer, the "world" should be recognised as a creation of language. Heidegger also realised that a new universal was needed. In Being and time, he focuses on "there-being" as a "being- 
in-the-world", but he still concentrates on historical being (geschichtliches Dasein). However, Gadamer (1991) points out that Heidegger did not want to once more introduce something essential or divine with his notion of Sein (Being). Much rather, his purpose was to introduce something like an event that opens the space in which hermeneutics could become (without a final foundation) a new universal (zum neuen Universale wird). This space is the dimension of language. ${ }^{13}$

Dooyeweerd (1938) switches from the idea of organic coherence to that of meaning coherence, and Seerveld explores a new understanding of symbolical objectification in the form of ambiguity and allusivity. The title of Croce's 1920 work is quite significant: Aesthetic as science of expression and general linguistic (cf. Croce, 1953 "expression" is indeed a "general linguistic" term). Also compare the terms used by Zuidervaart (1995): the aesthetic qualifying function is designated as "interpretable expressions" (purely semantic-hermeneutical categories). Even in 2001, when Seerveld once more argues in favour of "allusivity", he remarks that it "is more sound for doing justice to the symbolic character of Western as well as nonWestern craft and art" (Seerveld, 2001:163).

Croce, in his preface to Aesthetic (Naples, December 1901), writes:

If language is the first spiritual manifestation, and if the aesthetic form is language itself, taken in all its true scientific extension, it is hopeless to try to understand clearly the later and more complicated phases of the life of the spirit, when their first and simplest moment is ill known, mutilated and disfigured. (Croce, 1953:xxvii.)

One should not be surprised that Rookmaaker's first reaction to Seerveld's Ph.D. thesis (1958) was that in his aesthetics he argues the aesthetical aspect away (cf. Birtwistle, 1996:342).

\section{- The development of the meaning of the aesthetic aspect in Seerveld's thinking}

Seerveld starts from the notion of the "coherent symbolical objectification of meaning" (Seerveld, 1968:45). He then moves via ambiguity and allusivity (cf. Seerveld, 1979:284 ff.) to imaginitivty. This is a revision of his well-known definition: "Art is the symbolical objectification of certain meaning aspects of a thing [better: 'meaning- 
realities' - to accept a corrective comment from N. van Til], subject to the law of allusiveness" (Seerveld, 1979:290; cf. Seerveld, 1980: 132, note 12). What Seerveld does not realise is that the term nuancefulness indeed analogically reflects what he wants to avoid, namely a coherence with the numerical and spatial modes in those aspects to which he wants to restrict the meaning of beauty/ harmony, because he aims at avoiding beauty and harmony in his designation of the core meaning of the aesthetic aspect. However, since the terms nuancefulness and allusivity are synonymous to many-sidedness, it does not require much reflection to realise that the opposite of what was aimed for is achieved: the term many originally appears in the numerical mode while the element of sidedness refers to spatial configurations or sides. In addition to hidden nuances (many-sidedness), the term allusivity echoes the meaning of lingual ambiguities, thus showing that Seerveld's views appear to conflate the lingual and the aesthetic aspects. This reminds one immediately of the title of Croce's 1920 work, Aesthetic: as science of expression and general linguistic (cf. Croce, 1953). It is also noteworthy that Zuidervaart (1995:54) employs purely semantic-hermeneutical categories when advancing the idea that the aesthetic qualifying function of art works ought to be designated as "interpretable expressions". He designates "fit" as a technical norm, analogically derived from the spatial whole-parts relation. ${ }^{14}$

There are more arguments supporting the foundational position of the logical-analytical aspect of reality in relation to the sign mode. Language presupposes choice and the effect of this indispensible element of choice is that it always requires interpretation. Any lingual expression is characterised by these hallmarks. Moreover, interpretation exceeds any specific language, because whenever something is translated into another language further interpretation is needed. However, within a language the ever-present reality of metaphors also underscores the inherent feature required of interpretation. Metaphors entail an enriched element of suggestiveness precisely because they lack the univocality of clear-cut concepts.

Concepts, by contrast, although they can be named or designated, are not lingual by nature. For this reason they cannot be translated. Only the words designating a concept can be translated into a

14 Even in 2001, when Seerveld once more argues in favour of "allusivity", he remarks that it "is more sound for doing justice to the symbolic character of Western as well as non-Western craft and art" (Seerveld, 2001:163). 
different language. A concept or an argument (inference) is "grasped" or "understood". It depends upon immediate insight. Whereas language is formed presupposing the immediate functional foundation of the cultural-historical aspect, concepts are aquired on the basis of intuitive insight one either obtains this insight or one does not.

Furthermore, the well-known expression that we form a concept is employed in analogy to the cultural-historical subject-object relation. In terms of what we shall argue below, this expression actually represents a certain kind of metaphor.

Since concepts unite, through logical objectification, a multiplicity of universal features, they are blind to the individual. Language has access to the designation of universal concepts, but it can also point to what is individual, known as the deictic function of language. The same capacity is inherent in our (human) perception. Consider the construction of an "identity-kid" in criminal investigations. "Seeing" is of course also an ability of animals, although they lack the possibility of (logically) identifying and (lingually) pointing at the criminal.

\section{Analogy and metaphor}

We have seen that the connection between metaphor and analogy had already been made by Aristotle. Yet a more precise account is required to clarify what the underlying conditions in this respect are. One way to approach this problem is to further explore the nature of analysis. We have seen that logical analysis rests upon the nature of identification and distinction. The latter, in turn, presuppose similarities and differences. Discerning differences presupposes similarities and observing similarities presupposes differences. Therefore, two things can never be said to be absolutely different, because the assertion of this assumed difference is based on a crucial similairity - both are similar in "being things".

The most striking feature of an analogy is that it "short-circuits" the relationship between what is similar and what is different, because it succeeds in making either of the two subservient to the other. Consider a simple metaphor, such as the elbow of the finger. Bending is typical of an arm and of a finger. Therefore, this metaphor interconnects what is similar and what is different in such a way that either of the two is manifest in the other: either the difference is shown in the similarity or the other way around. In the case of the elbow of the finger the difference is shown in what is similar. The bending (i.e. what is similar) is different in the case of a finger and of 
an arm - which means that this difference is shown in the moment of similarity. Alternatively, in the moment of difference (a finger and an arm) what is similar manifests itself - for both a finger and an arm can bend.

Initially, after Elaine Botha started to introduce her serious interest in the theme of metaphoricity into our philosophical discussions, my first reflections experimented with the idea that we have to differentiate between two kinds of analogies: analogies between modal aspects, and analogies between entities. My first suggestion at the time (1981-1982 - including a discussion at an international conference of the Association for Calvinistic Philosophy in The Netherlands) - was to call analogies between aspects modal analogies and those between entities metaphors. While metaphors are replaceable by totally different metaphors, modal analogies (retrocipations and anticipations) can solely be "synonymised," that is, one can only provide synonymous terms without actually replacing what is at stake. The term life is synonymous with vital or vivid. As soon as these terms are replaced by terms derived from a different mode the original meaning of a modal analogy turns into an illigitimate reductionism.

Subsequent to my reading of Lakoff and Johnson (1999) on their understanding of conceptual metaphor I realised that there are more options to be considered - at least in terms of the dimensions of reality. If it is meaningful to distinguish between modal aspects and entities one should move beyond intermodal and interentity similarities and differences, because two further options surface: the similarities and differences between aspects and entities and between entities and modalities.

\section{Cross-domain mappings}

Lakoff and Johnson (1999) started to explore a scheme analogous to what is found in the mathematical function concept, manifested in their idea of source domains and target domains. As their starting point, they look at the scope and richness of our subjective mental life, where "subjective judgements" are made about "such abstract things as importance, similarity, difficulty, and morality" and where we meet "subjective experiences of desire, affection, intimacy, and achievement".

They are of the opinion that our conceptualisation of these experiences are derived from other domains of experience, which are sensorimotor domains. They give special attention to the cognitive 
mechanism operative in such conceptualisations, designated as conceptual metaphor. In another work Lakoff and Núñez (2000) define conceptual metaphor as "a cognitive mechanism for allowing us to reason about one kind of thing as if it were another. This means that metaphor is not simply a linguistic phenomenon, a mere figure of speech. Rather, it is a cognitive meganism that belongs to the realm of thought" (Lakoff \& Núñez, 2000:6). Lakoff and Johnson (1999:45) hold, therefore, that conceptual metaphor "is pervasive in both thought and language". They develop their views in terms of the embodiment of human existence. However, Botha (2006:28) correctly points out:

Lakoff and Johnson's anchoring of meaning in the bodily existence is a significant step away from the Cartesian and objectivist position, but falls short because of its location of meaning in the subjective and materialistic dimensions of reality.

The "embodied" nature of human subjectivity should rather be understood in terms of the subject-functions every human being has within all aspects of reality, and not merely related to the material, organic, and cognitive dimensions. Furthermore, it is not human subjectivity that gives rise to the various aspects of reality, because ultimately our humanity is conditioned by these aspects which make possible all our concepts and the rich variety of metaphors we can imaginatively invent.

Nonetheless, we have to ask the following question: is the idea of a conceptual metaphor sound? We have argued that a concept is a logical-analytical configuration and therefore not lingual by nature. Surely Lakoff and Johnson (1999) developed their view of "conceptual metaphor" carefully and systematically. It particularly applies, among other features, the idea of cross-domain mappings between source domains and target domains. These authors say that it is "a grounded, inference-preserving, cross-domain mapping" (Lakoff \& Núñez, 2000:6).

The strong element in this approach is the recognition of the innumerable images generated by cross-domain mappings that are employed by metaphors in all possible contexts of human endeavour. By and large, these cross-domain mappings concern similarities and differences between different (conceptualised) entitary (including event) domains, but also between modal domains and entitary domains (or vice versa). In all these cases, metaphors are instances of a distinct type of analogy in the sense defined by us. 
Although language is thought of as being constituted by arbitrary signs, 15 the possible ranges of semantic domains are not arbitrary. Brandt (2000:16) states: "Basic semantic domains are neither language-dependent nor culture-dependent, but languages, cultures, and individuals may fill them differently to some extent." The whole of experience may arbitrarily be divided into "comparable segments", it is "also possible to identify genuine parts of it that remain stable under cultural variation" (Brandt, 2000:16). Unfortunately the domains Brandt has in mind are rather entitary-like, for he identifies "a physical domain", "a social domain", "a mental domain", and "a speech-act domain" (Brandt, 2000:17). From an intermodal perspective one may first of all discern functional semantic domains, that is to say, instances where the semantic domain of a word embraces modal terms belonging to a specific aspect (or modal analogies of them). Thereafter one may contemplate the addition of semantic domains encompassing certain types of entities such as physical or social entities.

\section{The limits of substitution}

Since the choice of source and target domains is relatively arbitrary, it is understandable why we had to note that metaphors could be replaced by other ones unrelated to the initial ones for we have seen that only in the case of purely functional, modal analogies every attempt at such an exchange is unsuccessful. For example, different ways of capturing the spatial analogy within the structure of the social aspect are: social distance; social proximity ("next-to-eachother"); social super- and sub-ordination; social position; social wholes and parts, and so on.

All these expressions are in an important way connotatively synonymous insofar as they (analogically) reflect some or other structural feature of the spatial aspect. This ability to "synonymise" modal analogies is absent in the case of analogies between entities (or entities and modal properties or modal domains) as designated by metaphors. One may replace the metaphor "the nose of the car" by referring to the "bonnet of the car". Whereas we do have denotative synonymity in this case, connotative synonymity is absent.

15 De Saussure (1966:67) says that the "bond between the signifier and the signified is arbitrary". 


\section{Expanded conditions}

If we specify that the term metaphor does not apply to modal analogies, we still have to contemplate what can be included in the realm of metaphors. In fact, we have to expand our argument that aspectual analogies (similarities and differences between aspects of reality) ought to be distinguished from metaphors, because there are actually more possibilities (cf. Strauss, 2009:155 ff.).

Metaphors may explore analogies between different entities (E-E: "the nose of the car"), between entities and functional aspects (E-A: such as the "web of belief") and between aspects and entities (A-E: for example when evolutionary biology speaks of the origin of "life" instead of the genesis of living entities). Another A-E example is when we speak of the "social glue" of society.

The distinct cosmic dimension of time, embracing all aspects and entities, opens even further metaphorical possibilities. Take for example the biotic time order of birth, growth, maturation, ageing and dying. They can be related to the different phases of the day namely when early morning is designated as the birth of the day. If the direction is reversed, physical time and biotic time enable us to refer to the evening of life. The passage of time, in turn, may metaphorically be related to a flying object - for example when we remark that time is flying.

In other words, the metaphorical use of words strectches over all possible kinds of relationships between the various dimensions of reality, such as that of time, modal aspects and entities and processes. Yet, since a metaphor has its original seat within the sign mode and not within the logical-analytical aspect, the idea of conceptual metaphor is problematic - in spite of the claims of Lakoff and Johnson (1999) to the contrary. However, appreciating metaphors from the perspective of the sign mode does not deny the intermodal coherence between the sign mode and the logical-analytical mode. In fact, metaphoricity presupposes the conceptual-logical dimension (foundational aspect), but ought to be distinguished from it. If the sign mode and the logical-analytical mode were not different, the (lingual) identification present in metaphors would have been contradictory (such as in the case of the illogical concept of a square circle). 


\section{Conceptual metaphor}

Strictly speaking, the expression "conceptual metaphor", although described in an intelligible way, conflates the sign mode with its foundational logical-analytical aspect. Concepts are not words and for that reason they cannot be metaphors. Furthermore, in the absence of an articulated theory of modal functions, the nature of intermodal, interaspectual or interfunctional connections are distorted by the theory of conceptual metaphor. Ontic interconnections are presented as if they were, in fact, interconnections between conceptual domains. It also explains why the discussions of conceptual metaphor avoid an analysis of the ontic meaning of an aspect.

For example, instead of discussing the indefinability of love, as core meaning of the ethical aspect, Lakoff and Johnson (1999) embark on the investigation of the "concept of love" by asking whether or not it is "independent of the metaphors for love". The modal analogies within the structure of the ethical aspect are not metaphors and should, therefore, not be confused with genuine metaphors for love. When Lakoff and Johnson (1999) explain the metaphors for love, they clearly do not realise that they mix modal analogies and metaphors. They say: "Love is conventionally conceptualised, for example, in terms of a journey, physical force, illness, magic, madness, union, closeness, nurturance, giving of oneself, complementary parts of a single object and heat." (Lakoff \& Johnson, 1999:71.) The bi-unity of a couple in love embodies the numerical analogy within the modal structure of the ethical or moral aspect: it is a "loving union". The moral closeness or proximity of people loving each other highlights the spatial analogy within the structure of the moral aspect being close by or far apart are analogies of the meaning of spatial distance within moral relationships as reflected in language by terms such as kinship (blood relationship), marriage parters, bosom friend, and so on.

Let us consider an example of confusing intermodal (interaspectual) connections with conceptual domains in the sense of Lakoff and Johnson (1999). They refer to the rising level of water being poured into a glass which, according to them, enables the cross-domain mapping between quantity and verticality. 16

16 They (Lakoff \& Johnson, 1999:47-48) write:

This correspondence between quantity and verticality arises from a correlation in our normal everyday experiences, like pouring more water into the glass and seeing the level go up. Early in development, Johnson hypothesises, such correlations are 'conflations' in which 
When one enters into an analysis of what is given in reality (in a preconceptualised ontic sense), then one realises that spatial phenomena - such as vertical lines or verticality and horisontality - are founded in the meaning of number. Within space we can discern dimentionality as an order of extension in one, two, or three dimensions. Without the foundational quantitative meaning of one, two and three, the entire notion of spatial dimensions collapses into nothingness. Likewise, the spatial awareness of magnitude also factually presupposes number, because when we speak of different dimensions it is also possible to speak of length (one-dimensional extension), surface (two-dimensional extension), volume (three-dimensional extension), and so on. Therefore, verticality is embedded in dimensionality and the latter also collapses into nothingness when separated from its coherence with the quantitative meaning of the numbers employed in designating different kinds of magnitudes.

The structural meaning of the spatial aspect is intrinsically connected to the (foundational) quantitative meaning of number. Consequently, one should not confuse "conceptual domains" with "ontic functions", because the latter ultimately co-conditions both our (integral) experience and our concept formation. This confusion may also tempt us to deny ontic interconnections between modal aspects on the basis of the supposed disconnectedness of "conceptual domains". Lakoff and Núñez (2000:324) are even drawn into a position where their emphasis on "conceptual metaphor" convinces them that continuity and discreteness are opposites instead of belonging to mutually cohering but distinct ontic functions of reality.

\section{Concluding remark}

Metaphors indeed transcend the logical-analytical mode - without being able to cut their ties with the conceptual basis found in the logical aspect. Without the foundational role of (analytical) concept formation (thinking), the entire distinction between a source domain and a target domain, as well as the distinction between literal and metaphorical language, becomes meaningless. Precisely because a metaphor is not a concept, it can employ words metaphorically 
without violating the analytical scope of some or other concept to which the word(s) under consideration may refer.

\section{List of references}

ARISTOTLE. 2001 [1941]. The basic works of Aristotle. Ed. by R. McKeon with an introduction by C.D.C. Reeve. New York: The Modern Library.

BIRTWISTLE, G.M 1996. Filosofie van de kunst en de aesthetica. (In Van Woudenberg, R., ed. Kennis en werkelijkheid. Amsterdam: Buijten \& Schipperhijn. p. 342-370.)

BLACK, M. 1979. More about metaphor. (In Ortony, A., ed. Metaphor and thought. New York: Cambridge University Press. p. 1-24.)

BOTHA, M.E. 2006. Metaphor, embodiment and fiduciary beliefs in science. (In Lategan, L.O.K. \& Smith, J.H. Time and context relevant philosophy. Festschrift dedicated to D.F.M. Strauss. Bloemfontein: Association for Christian Higher Education. p. 17-36.)

BOTHA, M.E. 2007. Metaphor and its moorings, studies in the grounding of metaphorical meaning. Bern: Peter Lang.

BRANDT, P.A. 2000. The architecture of semantic domains - a grounding hypothesis in cognitive semiotics. Revista portuguesa der humanidades, 4(1 \& 2):11-51.

CROCE, B. 1953. Aesthetic as science of expression and general linguistic. 3rd ed. Trans. from the definitive Italian edition from 1920. New York: Noonday.

DE SAUSSURE, F. 1966. Course in general linguistics. Ed. by C. Bally \& A. Sechehaye. London: McGraw-Hill.

DE VLEESCHAUWER, H.J. 1952. Handleiding by die studie van die logika en die kennisleer. Pretoria: Moerau.

DIELS, H. \& KRANZ, W. 1959-1960. Die Fragmente der Vorsokratiker. Vol. 1-3. Berlin: Weidmannsche Verlagsbuchhandlung.

DOOYEWEERD, H. 1938. Recht en historie. Paper presented at the 23rd Scientific Gathering of the Free University of Amsterdam, 13 July 1938.

EIBL-EIBESFELDT, I. 2004. Grundriß der vergleichenden Verhaltensforschung: Ethologie. Hrsg. Vierkirchen-Pasenach: Buch Vertrieb Blank $\mathrm{GmbH}$.

ENCYCLOPEDIA BRITANNICA. 1975. Vol. 15. London: Hemingway Benton.

GADAMER, H.-G. 1991. Die Hermeneutik und der Diltheyschule. Philosophische Rundschau, 38(3):161-177.

KANT, I. 1969 [1783]. Prolegomena zu einer jeden künftigen Metaphysik die als Wissenschaft wird auftreten können. Hamburg: Felix Meiner edition.

KÖLLER, W. 1975. Semiotik und Metapher. Stuttgart: Metzier.

LAKOFF, G. \& JOHNSON, M. 1999. Philosophy in the flesh: the embodied mind and its challenge to western thought. New York: Basic Books.

LAKOFF, G. \& NÚNEEZ, R.E. 2000. Where mathematics comes from: how the embodied mind brings mathematics into being. New York: Basic Books.

MÄCKLER, A., Hrsg. 2000. 1460 Antworten auf die Frage: Was ist Kunst? Köln: DuMont.

NARR, K.J. 1976. Cultural achievements of early man. (In Altner, G. \& Hofer, H. Die Sonderstellung des Menschen. Stuttgart: Fischer. p. 98-152.)

SEERVELD, C.G. 1968. A Christian critique of art and literature. Toronto: The Association for Reformed Scientific Studies. 
SEERVELD, C.G. 1979. Modal aesthetics: preliminary questions with and opening hypothesis. (In Kraay, J. \& Tol, A., eds. Hearing and doing: philosophical essays dedicated to H.E. van Runner. Toronto: Wedge Publishing Foundation. p. 263-294.)

SEERVELD, C.G. 1980. Rainbows for the fallen world: aesthetic life and aesthetic task. Toronto: Tuppence.

SEERVELD, C.G. 2001. Christian aesthetic bread for the world. Philosophia reformata, 66(2):155-177.

STRAUSS, D.F.M. 2009. Philosophy: discipline of the disciplines. Grand Rapids: Paideia.

THOMAS AQUINAS. 1964. Summa theologica. Latin text and English translation, introductions, notes, appendices, and glossaries. New York, McGraw-Hill.

VAN NIEKERK, A. 1993. Rasionaliteit en relativisme: op soek na 'n rasionaliteitsmodel vir die menswetenskappe. Red. deur J. Mouton. Pretoria: HSRC. (Studies in research methodology.)

VERBURG, P.A. 1951. Enkele lijnen en feiten in de ontwikkeling der taaltheorie. (In Zuidema, S.U. \& Popma, K.J. Wetenschappelijke bijdragen door de leerlingen van Dr. D.H. Th. Vollenhoven, aangeboden ter gelegenheid van zijn 25-jarig hoogleraarschap aan de Vrije Universiteit. Franeker: Wever. p. 13-32.)

ZUIDERVAART, L. 1995. Fantastic things: critical notes towards a social ontology of the arts. Philosophia reformata, 60:37-54.

\section{Key concepts:}

analogies
concept
conceptual metaphor
language
metaphor
thought

\section{Kernbegrippe:}

analogieë

begrip

begripsmetafoor

denke

metafoor

taal 
